CAMPOS, Maria Bárbara de. Os aposentados e a Formação ao Longo da Vida. 2020. 118f. Dissertação. Programa de Pós-Graduação Stricto sensu do Mestrado em Educação Tecnológica. Diretoria de Pesquisa E Pós-Graduação, Centro Federal de Educação Tecnológica de Minas Gerais, Belo Horizonte, $2020 .^{1}$

\title{
OS APOSENTADOS E A FORMAÇÃO AO LONGO DA VIDA
}

\author{
Retirees and lifelong learning
}

CAMPOS, Maria Bárbara de ${ }^{2}$

\begin{abstract}
RESUMO
Esta pesquisa teve por objetivo compreender o sentido da formação realizada pelos aposentados após se aposentarem. Eles pertencem a um grupo de voluntários alfabetizadores de jovens e adultos de um comitê de cidadania de Belo Horizonte. Este grupo é constituído por 29 participantes, sendo 25 mulheres e quatro homens. Para realizar a pesquisa, recorreu-se às construções teóricas da "Formação ao longo da vida", tendo como principais referências os autores: Meirieu (2005), Lima (2007) e Tomasi e Ferreira (2013). Foi realizada uma pesquisa descritiva, de abordagem qualitativa e os procedimentos para a coleta de dados foram a realização de um questionário enviado aos 29 participantes do grupo e uma entrevista semiestruturada individual com uma amostra de seis dos 27 respondentes do questionário. Os dados foram tratados por meio da técnica de análise de conteúdo e os temas mais relevantes foram agrupados em categorias e subcategorias de análise. Foram identificadas 6 categorias: 1: Formação antes da aposentadoria; 2: Formação para a aposentadoria; 3: Formação após a aposentadoria; 4: Projeto de formação para o futuro; 5 : Diferença entre a formação antes e após a aposentadoria. Durante a análise percebeu-se outros temas recorrentes entre os entrevistados e criou-se, então, mais uma, a categoria 6: Outros aspectos apresentados sobre a aposentadoria. A partir da análise dos resultados, constatou-se que os aposentados interessam e buscam realizar atividades de formação, mesmo após a aposentadoria. As atividades citadas foram de variados tipos, como graduação, mestrado, idioma, terapias complementares, dança, canto, tocar instrumento musical, corte e costura, atividades voluntárias, entre outras. O sentido da formação para eles é de continuar se formando durante toda a vida e para a vida, ampliar a visão de mundo, retomar sonhos que não foram possíveis de serem realizados quando do trabalho ou
\end{abstract}

\footnotetext{
1 Orientador: Antônio de Pádua Nunes Tomasi, Pós doutor em Sociologia na UFMG, Doctorat de Sociologie pela Université Paris VII - Universite Denis Diderot e Mestre em Ciência Política pela Universidade Federal de Minas Gerais. Coordenador Geral do Simpósio Internacional Trabalho, Relações de Trabalho, Educação e Identidade (SITRE). E-mail: tomasi.antonio2020@gmail.com.

2 Mestra em Educação Tecnológica (PPGET/CEFET-MG), Especialista em Psicologia do Trabalho pela UFMG, Especialista em Gerência de Recursos Humanos pela FGV e Graduada em Psicologia pela PUC MG. Membro do comitê de organização do Simpósio Internacional Trabalho, Relações de Trabalho, Educação e Identidade (SITRE). E-mail: mariabarbara.incluir@gmail.com.
} 
que foram planejados para esta fase da vida. Antes da aposentadoria, a formação estava mais voltada para o trabalho e necessidade do mercado, como criticam os autores citados acima. E a diferença da formação após a aposentadoria, é que eles exercem a autonomia para escolher as atividades de acordo com o seu interesse e desejo, sendo estes a marca da Formação ao Longo da Vida. Os resultados apontaram para um perfil de aposentados mais ativos e dinâmicos que valorizam a trajetória de formação e, agora, com mais autonomia para fazer as suas escolhas de acordo com os seus interesses e desejos, continuam a trajetória de formação tanto pessoal quanto profissional. Há evidências que está modificando o conceito de aposentadoria de "retorno aos aposentos" e "inatividade" para uma vida mais ativa, de pessoas que participam de atividades de formação, socialização e buscam viver a longevidade com mais autonomia. Esta pesquisa contribuiu para o avanço dos estudos sobre a aposentadoria e a formação ao longo da vida, além de possibilitar novas reflexões. Há de se pontuar que este estudo abordou a escolha de um único segmento de atividade, funcionários de uma instituição financeira, sendo que a maioria vive em uma capital, Belo Horizonte, e região metropolitana, possui formação acadêmica e profissional e pertencem à classe média. Portanto, sugere-se para a realização de estudos futuros a ampliação para outras classes sociais, principalmente a classe menos favorecida econômica e socialmente, com pouca ou nenhuma formação escolar, além de outras categorias profissionais e de outras regiões brasileiras.

Palavras-chave: Formação ao longo da vida. Trabalho. Aposentadoria.

\section{AbSTRACT}

This research intended to comprehend the meaning of "formação" (professional development) done by retirees after their retirement. They belong to a volunteers literacy group for young and adult people of a citizenship committee from Belo Horizonte. This group is constituted by 29 participants with 25 women and 4 men. In order to perform this research, theoretical constructions from "Lifelong learning" were used and the main references were Meirieu (2005), Lima (2007) and Tomasi and Ferreira (2013). A descriptive research was done using qualitative approach and the procedures to collect data were applying a questionnaire to the 29 participants and a semi-structured personal interview with a sample of 6 people that replied the questionnaire. Data was processed according to the contents analysis technique and the most relevant topics were grouped in categories and subcategories of analysis. Six categories were identified: 1: Professional development before retirement; 2: Professional development for retirement; 3. Professional development after retirement; 4: Professional development project to the future; 5: Difference between Professional development before and after retirement. Other recurrent topics among interviewees were observed during analysis, so the 6th category was created: 6 : Other aspects presented about retirement. It was found that retirees are interested and look for Professional development activities, even after retirement. There were varied types of activities among the most mentioned ones such as graduation, master's, language courses, complementary therapies, dancing, singing, musical instruments, tailoring and sewing, volunteer activities, etc. The meaning of Professional development for them is to keep learning in life and for their lives, expanding their view of the world, coming back to their dreams that did not come true while they were working or that were planned to their current life stage. Results pointed out to a profile of more active and dynamic retirees who value their Professional development path. Now that they have more autonomy to make their own choices according to their interests and desires, they continue both their personal and professional formation path. There is some 
evidence that the concept of retirement as "withdrawing into seclusion" and "inactivity" is being changed to a more active life of people who participate in Professional development and socialization activities, and seek to enjoy their longevity with more autonomy. This research contributed to progress of studies about retirement and lifelong learning and it might also bring new thoughts on that subject. It should be noted that this study chose a single field of activity, employees of a financial institution, most of them living in a capital, Belo Horizonte and its metropolitan region, they have a good academic and professional formation and are middle class. Therefore, for future studies it is suggested to expand it to other social classes, specially the less economically and socially favoured classes with less or none school education, and also other professional categories and other Brazilian regions.

Keywords: Lifelong learning. Work. Retirement.

Data da submissão: 09/06/2021

Data da aprovação: 05/12/2021 